\title{
$\alpha$-Fluoromethylhistidine influences somatostatin content, binding and inhibition of adenylyl cyclase activity in the rat frontoparietal cortex
}

\author{
Lilian Puebla, Eduardo Arilla * \\ Unidad de Neuroendocrinología Molecular, Departamento de Bioquímica y Biología Molecular, Facultad de Medicina, Universidad de \\ Alcalá, Alcalá de Henares, 28871 Madrid, Spain
}

Received 14 November 1994; revised 19 April 1995; accepted 2 June 1995

\begin{abstract}
Slow-wave sleep, wakefulness, locomotor activity and learning and memory are regulated in similar ways by somatostatin (SS) and histamine. To clarify the possible role of endogenous histamine on the somatostatinergic system of the rat frontoparietal cortex, we studied the effect of $50 \mu \mathrm{g}$ of $\alpha$-fluoromethylhistidine ( $\alpha$-FMH), a specific inhibitor of histidine decarboxylase, administered intracerebroventricularly (i.c.v.) at 1,4 and $6 \mathrm{~h}$, on somatostatin-like immunoreactivity (SSLI) content and the SS receptor/effector system. The histamine content in the frontoparietal cortex decreased to about 67, 60 and $72 \%$ of control values at 1,4 and $6 \mathrm{~h}$ after $\alpha$-FMH administration, respectively. At $6 \mathrm{~h}$ after $\alpha$-FMH injection, there was an increase in SSLI content and a decrease in the number of SS receptors, with no change in the apparent affinity. No significant differences were seen for the basal and forskolin (FK)-stimulated adenylyl cyclase (AC) activities in the frontoparietal cortex of $\alpha$-FMH-treated rats when compared to the control group at all times studied. At $6 \mathrm{~h}$ after $\alpha$-FMH administration, however, the capacity of SS to inhibit basal and FK-stimulated AC activity in the frontoparietal cortex was significantly lower than in the control group. The ability of the stable GTP analogue 5'-guanylylimidodiphosphate (Gpp(NH)p) to inhibit FK-stimulated AC activity in frontoparietal cortex membranes was the same in the $\alpha$-FMH-treated (6 h) and control animals. Therefore, the decreased SS-mediated inhibition of AC activity observed in the $\alpha$-FMH-treated rats is not due to an alteration at the guanine nucleotide-binding inhibitory protein $\left(G_{i}\right)$ level but rather may be due to the decrease in the number of SS receptors. Taken together, these data suggest that $\alpha$-FMH influences the sensitivity to SS in the rat frontoparietal cortex.
\end{abstract}

Keywords: $\alpha$-Fluoromethylhistidine; Somatostatin receptor; Adenylyl cyclase; Rat; Frontoparietal cortex

\section{Introduction}

It is generally accepted that the somatostatinergic and histaminergic systems exert similar effects on sleep-wakefulness [1-4], memory and learning [5-7]

\footnotetext{
* Corresponding author. Fax: +34 18854585 .
}

and motor activity $[1,8]$. An anatomical basis for the interaction between the somatostatinergic and histaminergic systems has also been provided by the observations of histaminergic nerve terminals in cerebral regions rich in SS content and SS receptors [9-11]. Although the effects of somatostatin (SS) on brain histamine content have been studied [12], the 
effects of endogenous histamine on the rat somatostatinergic system are mainly unknown. In a recent study carried out by this laboratory, we observed that exogenous histamine increases the SS receptor/effector system in the rat frontoparietal cortex, inducing both an increase in the number of SS receptors and in SS-mediated inhibition of AC activity [13]. These effects were shown to be specifically mediated by histamine receptors since they were prevented by pretreatment with the histamine $\mathrm{H}_{1}$ and $\mathrm{H}_{2}$ receptor antagonists mepyramine and cimetidine, respectively. The aim of the present study, thus, was to clarify the possible role of endogenous histamine on the rat cerebral somatostatinergic system. Therefore, we examined the effects of inhibition of histamine synthesis by the histidine decarboxylase inhibitor $\alpha$-fluoromethylhistidine ( $\alpha$-FMH) $[14,15]$ on SS receptors in rat frontoparietal cortex membranes. Since the post-receptor mechanism of action of SS includes, at least in part, the inhibition of adenylyl cyclase (AC) activity via GTP binding ' $G$ proteins' [16,17], we have studied SS-inhibited AC activity in frontoparietal cortex membranes from control and $\alpha$-FMH-treated rats. Low concentrations of the stable GTP analogue 5'-guanylylimidodiphosphate (Gpp(NH)p) were employed to detect functional guanine nucleotide-binding inhibitory protein $\left(G_{i}\right)$ activity by inhibiting basal $\mathrm{AC}$ activity previously amplified by forskolin (FK). In addition, SSLI and histamine content were determined.

\section{Materials and methods}

\subsection{Chemicals}

Synthetic $\mathrm{Tyr}^{11}{ }^{1}$-somatostatin ( $\mathrm{Tyr}^{11}$-SS) and SS14 were purchased from Universal Biologicals Ltd. (Cambridge, UK); carrier-free $\mathrm{Na}{ }^{125}$ I (IMS 30, 100 $\mathrm{mCi} / \mathrm{ml}$ ) was purchased from the Radiochemical Centre (Amersham, UK); bacitracin, phenylmethylsulfonyl fluoride (PMSF), 3-isobutyl-1-methylxanthine (IBMX), bovine serum albumin (BSA), GTP, FK and Gpp(NH)p were supplied by Sigma Química (Madrid, Spain). $\alpha$-FMH was kindly supplied by Merck, Sharp and Dome Research Laboratories (Rathway, NJ, USA). The rabbit antibody used in the radioimmunoassay technique was purchased from the Radiochemical Center (Amersham, UK). This antiserum was raised in rabbits against SS-14 conjugated to BSA and is specific for SS, but since SS-14 also constitutes the C-terminal portions of both SS-25 and SS-28, the antiserum does not distinguish between these 3 forms. Cross-reactivity with other peptides was less than $0.5 \%$. Cross-reaction with several SS analogues demonstrated that neither the $\mathrm{N}$-terminal glycine nor the $\mathrm{C}$-terminal cysteine residue is required for antibody binding, suggesting that the antigen site is directed towards the central part of the molecule containing the tryptophan residue. The binding of SS-14 to its antibody does not depend on an intact disulfide in the molecule since breaking of the disulfide bond by reaction with $0.1 \%$ mercaptoethanol (boiling water bath, $5 \mathrm{~min}$ ) did not change peptide immunoreactivity.

\subsection{Experimental animals}

Thirty female Wistar rats weighing $200-250 \mathrm{~g}$ were used in this study since previous studies with male Wistar rats carried out by our laboratory showed similar values of SS receptors and SS content in the control group [18]. All rats used were at the same stage of the estrous cycle (beginning of the cycle). Rats were maintained on a 12-h light/dark cycle (07.00-19.00 h) and allowed free access to food. $\alpha$-FMH was dissolved in saline and administered intracerebroventricularly (i.c.v.) in a volume of 10 $\mu 1$ according to the method described by Noble et al. [19] at a dose of $50 \mu \mathrm{g}$ as previously described [20]. In all experiments, control animals received $10 \mu \mathrm{l}$ of saline. The rats were decapitated 1,4 , and $6 \mathrm{~h}$ after $\alpha$-FMH administration since it has been previously reported that a significant decrease in histamine content in the rat frontoparietal cortex is achieved at these time periods [20]. The brain was rapidly removed and the frontoparietal cortex was dissected over ice according to the method of Glowinski and Iversen [21].

\subsection{Determination of brain histamine}

After homogenization of frontoparietal cortex in $3 \%$ perchloric acid containing $5 \mathrm{mM} \mathrm{Na}{ }_{2}$-EDTA with a Polytron homogenizer at the maximum setting for $10 \mathrm{~s}$ in an ice bath, the homogenate was cen- 
trifuged at $10,000 \mathrm{~g}$ for $30 \mathrm{~min}$ at $4^{\circ} \mathrm{C}$ and stored at $-80^{\circ} \mathrm{C}$ until use. Fifty $\mu \mathrm{l}$ of the clear supernatant were injected into an HPLC-fluorometric system and histamine was measured by the $\alpha$-phthalaldehyde method as described by Yamatodani et al. [22]. The minimum detection limit of this method was 0.05 pmol, and the intra- and inter-assay coefficients of variation were 3.3 and $6.8 \%$, respectively.

\subsection{Tissue extraction and SS radioimmunoassay}

For SSLI measurements, the frontoparietal cortex was rapidly homogenized in $1 \mathrm{ml} 2 \mathrm{M}$ acetic acid using a Brinkman polytron (setting 5,30 s). Extracts were boiled for $5 \mathrm{~min}$ in a water bath, chilled in ice, and aliquots $(100 \mu \mathrm{l})$ were removed for protein determination [23]. The homogenates were subsequently centrifuged at $15,000 \mathrm{~g}$ for $15 \mathrm{~min}$ at $4^{\circ} \mathrm{C}$ and the supernatant was neutralized with $2 \mathrm{M} \mathrm{NaOH}$. Extracts were immediately stored at $-70^{\circ} \mathrm{C}$ until assay. The SSLI content was measured in tissue extracts by a modified radioimmunoassay method [23], with a sensitivity limit of $10 \mathrm{pg} / \mathrm{ml}$. Incubation tubes prepared in duplicate contained $100 \mu \mathrm{l}$ samples of unknown or standard solutions of $0-500 \mathrm{pg}$ cyclic SS tetradecapeptide diluted in phosphate buffer $(0.05 \mathrm{M}, \mathrm{pH} 7.2$, containing $0.3 \%$ BSA, $0.01 \mathrm{M}$ EDTA), $200 \mu 1$ of appropriately diluted anti-SS serum, $100 \mu 1$ of freshly prepared ${ }^{125}{ }^{I-T y r}{ }^{11}$-SS diluted in buffer to give $6000 \mathrm{cpm} /$ assay tube (equivalent to $5-10 \mathrm{pg}$ ), and enough buffer to give a final volume of $0.8 \mathrm{ml}$. All reagents as well as the assay tubes were kept chilled in ice before incubation at $4^{\circ} \mathrm{C}$ for $48 \mathrm{~h}$. Separation of bound and free hormone was accomplished by the addition of $1 \mathrm{ml}$ dextran-coated charcoal (dextran T70: $0.2 \% \mathrm{w} / \mathrm{v}$, Pharmacia, Uppsala, Sweden; charcoal: Norit A 2\% w/v, Serva, Feinbiochemica, Heidelberg, Germany). Dilution curves for each brain area were parallel to the standard curve. The intra- and inter-assay variation coefficients were 6.8 and $8 \%$, respectively.

\subsection{Binding assay}

$\mathrm{Tyr}^{11}$-SS was radioiodinated by chloramine-T iodination [24]. Separation of iodinated SS from unincorporated iodine was carried out on a Sephadex G-25 (fine) column equilibrated and eluted with 0.1
$\mathrm{M}$ acetic acid containing BSA $(0.1 \%, \mathrm{w} / \mathrm{v})$. The specific activity of the radioligand was $600 \mathrm{Ci} / \mathrm{mmol}$.

Membranes from rat frontoparietal cortex were prepared as previously described by Reubi et al. [25]. Membrane protein was determined by the method of Lowry et al. [26] using BSA as a standard. Specific SS binding was measured according to the modified method of Czernik and Petrack [27]. Briefly, the membranes $(0.15 \mathrm{mg}$ protein $/ \mathrm{ml})$ were incubated in $250 \mu \mathrm{l}$ of a medium containing $50 \mathrm{mM}$ Tris- $\mathrm{HCl}$ buffer (pH 7.5), $5 \mathrm{mM} \mathrm{MgCl} 2,0.2 \%(\mathrm{w} / \mathrm{v})$ BSA and $0.1 \mathrm{mg} / \mathrm{ml}$ bacitracin with $250 \mathrm{pM}^{125}{ }^{1-T_{y r}{ }^{11}-\mathrm{SS}}$ either in the absence or presence of $0.01-10 \mathrm{nM}$ unlabeled SS. After incubation for $60 \mathrm{~min}$ at $30^{\circ} \mathrm{C}$, bound and free ligand were separated by centrifugation at $11,000 \mathrm{~g}$ for $2 \mathrm{~min}$, and the radioactivity in the resultant pellet was measured in a Kontron gamma-counter. Non-specific binding, that is, binding occurring in the presence of a high concentration $\left(10^{-7} \mathrm{M}\right)$ of unlabeled SS, represented about $20 \%$ of the binding observed in the absence of unlabeled peptide. This non-specific component was subtracted from the total bound radioactivity in order to obtain the corresponding specific binding.

\subsection{Evaluation of radiolabeled peptide degradation}

To determine the extent of tracer degradation during incubation, we measured the ability of preincubated peptide to bind to fresh membranes as previously described [28]. Briefly, ${ }^{125}{ }^{\text {I-Tyr }}{ }^{11}-$ SS (250 pM) was incubated with membranes from rat frontoparietal cortex $(0.15 \mathrm{mg}$ protein $/ \mathrm{ml})$ for $60 \mathrm{~min}$ at $30^{\circ} \mathrm{C}$. After this preincubation, aliquots of the medium were added to fresh membranes and incubated for an additional $60 \mathrm{~min}$ at $30^{\circ} \mathrm{C}$. The fraction of the added radiolabeled peptide which was specifically bound during the second incubation was measured and expressed as a percentage of the binding that had been obtained in control experiments performed in the absence of membranes during the preincubation period.

\subsection{Adenylyl cyclase assay}

AC activity was measured as previously reported [29] with minor modifications. Briefly, rat frontoparietal cortex membranes $(0.06 \mathrm{mg} / \mathrm{ml})$ were in- 
cubated with $1.5 \mathrm{mM}$ ATP, $5 \mathrm{mM} \mathrm{MgSO}{ }_{4}, 10 \mu \mathrm{M}$ GTP, an ATP-regenerating system $(7.5 \mathrm{mg} / \mathrm{ml}$ creatine phosphate and $1 \mathrm{mg} / \mathrm{ml}$ creatine kinase), $1 \mathrm{mM}$ IBMX, $0.1 \mathrm{mM}$ PMSF, $1 \mathrm{mg} / \mathrm{ml}$ bacitracin, $1 \mathrm{mM}$ EDTA, and test substances $\left(10^{-4} \mathrm{M}\right.$ SS or $10^{-5} \mathrm{M}$ FK) in $0.1 \mathrm{ml}$ of $0.025 \mathrm{M}$ triethanolamine $/ \mathrm{HCl}$ buffer ( $\mathrm{pH} 7.4$ ). After a $15 \mathrm{~min}$ incubation at $30^{\circ} \mathrm{C}$, the reaction was stopped by heating the mixture for 3 $\mathrm{min}$. After cooling, $0.2 \mathrm{ml}$ of an alumina slurry $(0.75$ $\mathrm{g} / \mathrm{ml}$ in triethanolamine $/ \mathrm{HCl}$ buffer, $\mathrm{pH} 7.4$ ) was added and the suspension was centrifuged. The supernatant was taken for assay of cyclic AMP (cAMP) by the method of Gilman [30]. The SS concentration used was that necessary to achieve inhibition of rat [17] and human [31,32] brain AC. FK was used at a concentration that could effectively stimulate the catalytic subunit of rat AC [17].

\subsection{Data analysis}

The computer program LIGAND [33] was used to analyze the binding data. The use of this program enabled models of receptors which best fit a given set of binding data to be selected. The same program was also used to present data in the form of Scatchard plots [34] and to compute values for receptor affinity $\left(k_{\mathrm{d}}\right)$ and density $\left(B_{\max }\right)$. Statistical comparisons of all the data were carried out by a two-way analysis of variance (ANOVA). Bonferroni-corrected post hoc $t$-tests were used after a significant overall treatment effect was found. Means among groups were considered significantly different when the $P$-value was

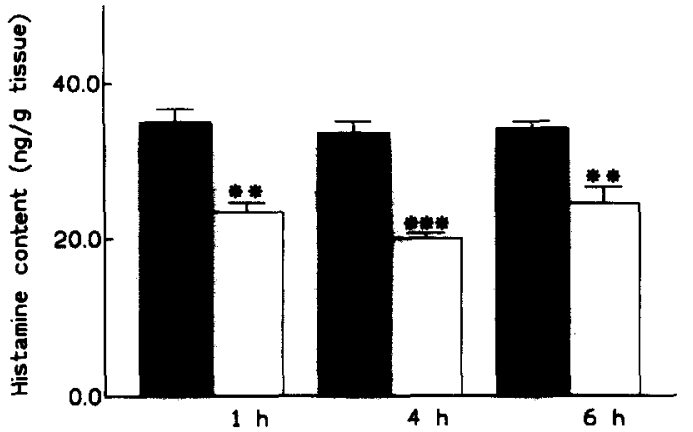

Fig. 1. Effect of a single intracerebroventricular injection of $\alpha$-fluoromethylhistidine ( $\alpha$-FMH) $(50 \mu \mathrm{g})$ on histamine content in the rat frontoparietal cortex at 1,4 and $6 \mathrm{~h}$ after drug administration. Solid bars correspond to control animals $(n=5$ rats in each group) and open bars correspond to rats treated with $\alpha$-FMH at $1(n=5), 4(n=5)$ or $6 \mathrm{~h}(n=5)$ after injection. Values are expressed as the mean \pm S.E.M. of 5 separate determinations performed in duplicate. Statistical comparison versus control: ${ }^{* *} P<0.01 ;{ }^{* *} P<0.001$.

less than 0.05 . Each individual experiment was performed in duplicate.

\section{Results}

The i.c.v. administration of $\alpha$-FMH at a dose of $50 \mu \mathrm{g}$ significantly decreased histamine content in the rat frontoparietal cortex to about 67,60 and $72 \%$ of control values at 1,4 and $6 \mathrm{~h}$ after its administration, respectively (Fig. 1). This decrease in histamine content was associated with an increase in SSLI

Table 1

Effect of $\alpha$-Fluoromethylhistidine ( $\alpha$-FMH) $(50 \mu \mathrm{g}$ ) administered intracerebroventricularly (i.c.v.) at 1,4 or 6 h on somatostatin-like immunoreactivity (SSLI) content and equilibrium parameters for somatostatin (SS) binding to rat frontoparietal cortex membranes

\begin{tabular}{|c|c|c|c|c|}
\hline \multirow[t]{2}{*}{ Groups } & \multicolumn{2}{|l|}{ SS receptors } & \multirow[t]{2}{*}{ SSLI } & \multirow[t]{2}{*}{$n$} \\
\hline & $\overline{B_{\max }}$ & $K_{\mathrm{d}}$ & & \\
\hline Control $1 \mathrm{~h}$ & $363 \pm 26$ & $0.40 \pm 0.03$ & $9.70 \pm 0.91$ & 5 \\
\hline$\alpha$-FMH 1 h & $365 \pm 24$ & $0.38 \pm 0.04$ & $11.25 \pm 1.74$ & 5 \\
\hline Control $4 \mathrm{~h}$ & $359 \pm 17$ & $0.34 \pm 0.03$ & $11.92 \pm 0.99$ & 5 \\
\hline$\alpha$-FMH 4 h & $369 \pm 20$ & $0.29 \pm 0.02$ & $10.79 \pm 0.84$ & 5 \\
\hline Control $6 \mathrm{~h}$ & $363 \pm 17$ & $0.38 \pm 0.04$ & $10.4 \pm 1.0$ & 5 \\
\hline$\alpha$-FMH 6 h & $249 \pm 13^{b}$ & $0.29 \pm 0.03$ & $20.2 \pm 1.1^{\mathrm{a}}$ & 5 \\
\hline
\end{tabular}

Binding parameters were calculated from Scatchard plots by linear regression. Units for SSLI are ng of SS per mg of protein, units for $K_{\mathrm{d}}$ are $\mathrm{nM}$ and units for $B_{\max }$ are femtomoles of SS bound per $\mathrm{mg}$ of protein. The results are represented as the means $\pm S$.E.M. of five separate experiments performed in duplicate. $n=$ number of animals in each experimental group. Statistical comparison versus control: ${ }^{\mathrm{a}} P<0.05,{ }^{\mathrm{b}} P<0.01$. 
content at $6 \mathrm{~h}$ after the drug administration, with no changes being observed at either 1 or $4 \mathrm{~h}$ (Table 1 ).

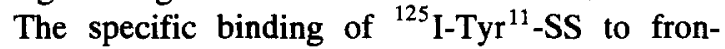
toparietal cortex membranes was time-dependent; an apparent equilibrium was observed between 50 and $180 \mathrm{~min}$ at $30^{\circ} \mathrm{C}$ (data not shown). All subsequent binding experiments were therefore conducted at $30^{\circ} \mathrm{C}$ for $60 \mathrm{~min}$. Peptide degradation was determined to rule out the possibility of different SS degrading activities which might have affected the interpretation of the results. Membranes from each experimental group, however, showed a similar peptide degradation capacity and the values varied by no more than $10 \%$ among the experimental groups, thus making it possible to compare their type values.

Increasing concentrations of unlabeled SS inhibited the specific binding of ${ }^{125} \mathrm{I}-\mathrm{Tyr}^{11}$-SS to rat frontoparietal cortex membranes from both the control and the $\alpha$-FMH-treated groups (Fig. 2, left panel). The specific binding of the tracer to frontoparietal cortex membranes, however, was significantly lower in rats treated with $\alpha$-FMH at $6 \mathrm{~h}$ as compared with controls (Fig. 2, left panel) whereas no changes were observed at 1 or $4 \mathrm{~h}$. Scatchard analysis of the binding data indicate that the decrease in tracer binding observed at $6 \mathrm{~h}$ was due to a decrease in the maximal number of SS receptors, with no change in the apparent affinity (Table 1; Fig. 2, right panel).

SS has been shown to inhibit AC activity through interaction with specific SS receptors coupled to the enzyme via a $G_{i}$ protein $[16,17]$. Therefore, we studied SS-modulated AC activity by incubating frontoparietal cortex membranes with SS $\left(10^{-4} \mathrm{M}\right)$

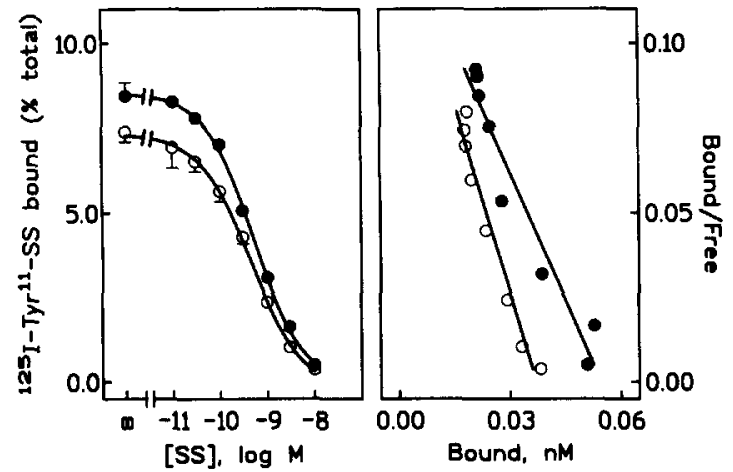

Fig. 2. Left panel: competitive inhibition of specific ${ }^{125} \mathrm{I}-\mathrm{Tyr}^{11}$. somatostatin ( ${ }^{125} \mathrm{I}-\mathrm{Tyr}^{11}$-SS) binding by unlabeled SS to membranes from rat frontoparietal cortex. Membranes $(0.15 \mathrm{mg}$ protein $/ \mathrm{ml}$ ) were incubated for $60 \mathrm{~min}$ at $30^{\circ} \mathrm{C}$ in the presence of $250 \mathrm{pM}{ }^{125} \mathrm{I}^{-} \mathrm{Tyr}^{11}-\mathrm{SS}$ and increasing concentrations of native peptide. Points correspond to control rats $(O)(n=5)$ and $\alpha$-fluoromethylhistidine ( $\alpha$-FMH)-treated rats at $6 \mathrm{~h}$ after $\alpha$-FMH injection $(O)(n=5)$. Each point is the mean of 5 individual experiments performed in duplicate. Right panel: Scatchard analysis of the binding data.

either in the presence or absence of FK $\left(10^{-5} \mathrm{M}\right)$, a direct $\mathrm{AC}$ activator. No significant differences in basal or FK-stimulated AC activity were observed between the control and the $\alpha$-FMH-treated rats at all times studied. At $6 \mathrm{~h}$ after $\alpha$-FMH administration, however, the capacity of SS to inhibit both basal and FK-stimulated AC activity in frontoparietal cortex membranes was significantly lower than in the control group (Table 2; Fig. 3).

Functional $G_{i}$ activity was examined in frontoparietal cortex membranes of control and $\alpha$-FMH

Table 2

Effect of somatostatin (SS) $\left(10^{-4} \mathrm{M}\right)$ and forskolin $(\mathrm{FK})\left(10^{-5} \mathrm{M}\right)$ on adenylyl cyclase (AC) activity (pmol cAMP $\left./ \mathrm{min} / \mathrm{mg} \mathrm{protein}\right)$ in frontoparietal cortex membranes from control rats $(n=5)$ and $\alpha$-fluoromethylhistidine-treated rats $(n=5)$

\begin{tabular}{lcc}
\hline & \multicolumn{2}{l}{$\alpha$-Fluoromethylhistidine (6 h) } \\
\cline { 2 - 3 } & Control & Treated \\
\hline Basal activity & $120 \pm 2$ & $132 \pm 3$ \\
Basal activity $+10^{-4}$ M SS & $94 \pm 2$ & $119 \pm 3^{\mathrm{c}}$ \\
\% SS inhibition of basal activity & $22 \pm 1$ & $10 \pm 1^{\mathrm{b}}$ \\
Basal activity $+10^{-5} \mathrm{M}$ FK & $664 \pm 15$ & $694 \pm 21$ \\
Fold FK estimulation of basal activity & $5.4 \pm 0.3$ & $5.3 \pm 0.3$ \\
Basal activity $+10^{-5}$ M FK $+10^{-4}$ M SS & $516 \pm 20$ & $614 \pm 21^{\mathrm{a}}$ \\
\% SS inhibition of FK-stimulated activity & $22 \pm 2$ & $12 \pm 2^{\mathrm{b}}$ \\
\hline
\end{tabular}

Values represent the mean \pm S.E.M. of 5 separate experiments performed in duplicate. $n=$ number of animals in each experimental group. Statistical comparison versus control: ${ }^{\mathrm{a}} P<0.05 ;{ }^{\mathrm{b}} P<0.01 ;{ }^{\mathrm{c}} P<0.001$. 


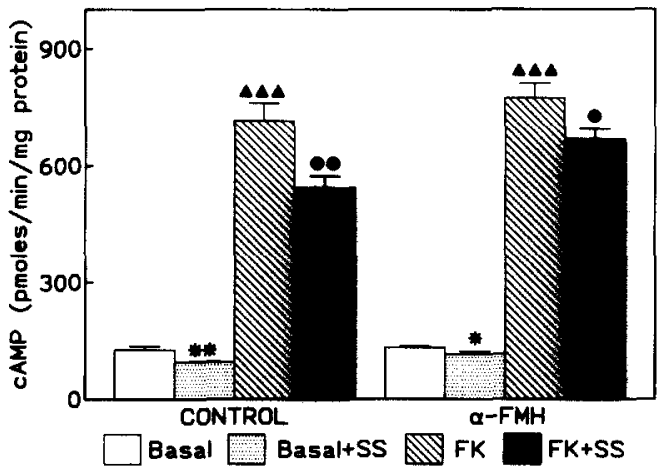

Fig. 3. Comparison of the ability of somatostatin (SS) to inhibit adenylyl cyclase (AC) activity in frontoparietal cortex membranes of control rats $(n=5)$ and $\alpha$-fluoromethylhistidine ( $\alpha$-FMH)treated rats at $6 \mathrm{~h}$ after $\alpha$-FMH administration $(n=5)$. Membrane preparations were incubated with or without SS $\left(10^{-4} \mathrm{M}\right)$ in the absence (basal) or presence of $10^{-5} \mathrm{M}$ forskolin (FK). Data are expressed as the mean \pm S.E.M. of 5 separate experiments performed in duplicate. Statistical analysis was performed by ANOVA. $\triangle P<0.001$ : comparison between basal and FKstimulated groups. ${ }^{*} P<0.05 ;{ }^{*}{ }^{*} P<0.01$ : comparison between basal and SS-treated groups. $P<0.05 ; \bullet \bullet P<0.01$ : comparison between FK and FK + SS groups.

$(6 \mathrm{~h})$-treated rats in order to determine whether the decrease in SS receptors and/or SS-modulated AC activity observed at $6 \mathrm{~h}$ after drug administration was

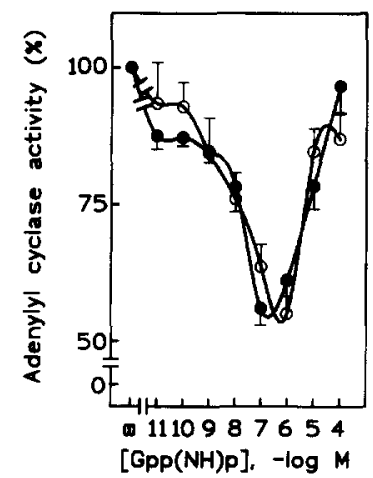

Fig. 4. Dose-effect curves for $5^{\prime}$-guanylylimidodiphosphate [Gpp $(\mathrm{NH})$ p]-mediated inhibition of adenylyl cyclase (AC) activity in rat frontoparietal cortex membranes from control rats (O) $(n=5)$ and $\alpha$-fluoromethylhistidine ( $\alpha$-FMH)-treated rats (O) $(n=5)$ at $6 \mathrm{~h}$ after $\alpha$-FMH administration. Curves for the action of $\mathrm{Gpp}(\mathrm{NH}) \mathrm{p}$ on $\mathrm{AC}$ activity were carried out in the presence of $3 \times 10^{-6} \mathrm{M}$ forskolin (FK) and the indicated concentrations of $\mathrm{Gpp}(\mathrm{NH})$ p. Data are expressed as a percentage of FK-stimulated AC activity in the absence of $\mathrm{Gpp}(\mathrm{NH}) \mathrm{p}(100 \%)$. The results are given as the mean \pm S.E.M. of 5 separate experiments performed in duplicate. No statistically significant differences were obtained between the control and $\alpha$-FMH-treated rats. due to an alteration at the $G_{i}$ level. In the presence of FK $\left(3 \times 10^{-6} \mathrm{M}\right)$, which amplifies basal AC activity, increasing concentrations of $\mathrm{Gpp}(\mathrm{NH}) \mathrm{p}$ produce an inhibitory effect on AC activity that has been used by several investigators as a measure of $G_{i}$ function [35]. The ability of $\mathrm{Gpp}(\mathrm{NH}) \mathrm{p}$ to inhibit FK-stimulated AC activity was similar in frontoparietal cortex membranes from control and $\alpha$-FMH (6 h)-treated rats (Fig. 4).

\section{Discussion}

$\alpha$-FMH is an irreversible and specific inhibitor of histidine decarboxylase $[14,15]$ and even a single administration can deplete neuronal histamine in the animal brain $[36,37]$. Thus, $\alpha$-FMH has been considered a useful tool to examine the functions of neuronal histamine in the brain. As shown in Fig. 1, a significant reduction in histamine content after $\alpha$ FMH injection was observed between 1 and $6 \mathrm{~h}$ in the cerebral cortex, in agreement with other authors [19]. In the mammalian brain, histamine is thought to be stored in two anatomically distinct pools, that is, the neuronal pool, with a rapid turnover, and the mast cell pool, with a very slow turnover [38-41]. The half-life of neuronal histamine in the rat brain is reported to be approximately $60 \mathrm{~min}$, which is much shorter than that in mast cells (almost 4 days) [3843]. In the present study, $\alpha$-FMH caused a $33 \%$, $40 \%$ and $28 \%$ reduction in histamine levels in the frontoparietal cortex at 1,4 and $6 \mathrm{~h}$ after its administration, respectively. Garbarg et al. [42] have shown that blockade of histidine decarboxylase activity by $\alpha$-FMH injection decreases brain histamine only in the neuronal pool and does not affect the non-neuronal sources (mainly mast cells). In addition, Maeyama et al. [44] found almost complete depletion of brain histamine in $\mathrm{W} / \mathrm{W}^{\mathrm{v}}$ mice, which are devoid of mast cells. Therefore, it is probable that the residual histamine in the rat frontoparietal cortex after $\alpha$-FMH administration may be due to the histamine content present in mast cells.

An i.c.v. administration of $\alpha$-FMH was chosen in this study instead of an intraperitoneal (i.p.) injection for several reasons. Firstly, Garbarg et al. [42] reported that i.p. injection of $\alpha$-FMH decreased histidine decarboxylase activity not only in various brain 
regions, but also in gastric tissues. In addition, Sakurai et al. [45] demonstrated that $\alpha$-FMH concentrations in the peripheral tissues were much higher than that determined in the brain after intravenous injection. Thus, an i.c.v. route of administration would eliminate any possible systemic effects of the drug which might affect the interpretation of the results.

Because ${ }^{125}{ }^{I-T y r}{ }^{11}$-SS acts biologically like the native peptide [46], it was chosen as the tracer. The extent of SS degradation in this study was relatively important, but it reached similar values in all the experimental groups, so it was possible to compare their type values. The values calculated for $k_{\mathrm{d}}$ and binding can be modified by ${ }^{125}{ }^{\text {I-Tyr }}{ }^{11}$-SS degradation and so they must be considered as apparent.

In the control rats, the SSLI content was similar to that previously reported by others $[47,48]$. The inhibition of histamine synthesis induced by $\alpha$-FMH was accompanied by a rise in SSLI content at $6 \mathrm{~h}$ after $\alpha$-FMH administration, although to date, the mechanism is unknown. The studies of the effect of histamine on SS release or SS intracellular content are not clear $[49,50]$. In some studies, histamine seems to act as a mild inhibitor of SS release in fetal cultured cerebral cortical cells from rat brain, although this effect is not significant at concentrations of up to $10^{-5} \mathrm{M}[49,50]$. In the present study, no change in SSLI content was detected at either 1 or 4 $h$, which suggests that a certain time is required for the effect on SSLI content to take place. It is possible that the change in SSLI content at $6 \mathrm{~h}$ following $\alpha$-FMH administration may be secondary to the decrease in SS receptors. This is consistent with studies on adrenergic receptors in which changes in the turnover of dopamine following clonidine administration were shown to be secondary to its effects on adrenergic receptors [51,52].

The treatment with $\alpha$-FMH decreased ${ }^{125}{ }^{1-T y r}{ }^{11}$. SS binding in membranes from the rat frontoparietal cortex at $6 \mathrm{~h}$ after its administration. Scatchard plot analysis of the SS-receptor interaction demonstrated a $32 \%$ reduction in the maximal binding capacity in the $\alpha$-FMH-treated group and an association constant in the same magnitude range as that of the control rats. The fact that the Scatchard plots are linear in all the experimental groups is not proof of a single binding site. In effect, 5 different subtypes of SS receptors have recently been cloned [53], all of which appear to be expressed in the rat brain [54] and which have high affinity for SS-14. Thus, a linear Scatchard plot reveals only that all SS receptor subtypes have similar affinity for the radioligand used.

The mechanisms by which $\alpha$-FMH administration reduces the number of SS receptors in the frontoparietal cortex is open to speculation, although both direct and indirect effects can be considered. At present, we can only speculate that the effects of $\alpha$-FMH on the number of SS receptors in the frontoparietal cortex are caused by changes in histaminergic transmission which then transsynaptically regulate the number of SS receptors. The presence of SS receptors in parts of the brain that have histaminergic nerve fibers in close proximity lends support to this notion [9-11]. In addition, the results of a variety of recent experiments suggest that neural input may regulate the concentration of peptides, proteins and enzymes in a variety of systems [55,56].

Alternatively, the regulation of the somatostatinergic system may be indirect. The inhibition of histamine synthesis caused by $\alpha$-FMH produces neuroendocrine alterations that may induce changes in the SS receptors. It has been demonstrated that $\alpha$ FMH administration leads to an inhibition of corticosterone secretion [57] and prolactin secretion by restraint stress [58] as well as an increase in plasma vasopressin [59]. The reduction in the binding capacity after $\alpha$-FMH ( $6 \mathrm{~h}$ ) administration was not due to a deleterious effect of $\alpha$-FMH on total protein synthesis since Slotkin et al. [60] have shown that $\alpha$-FMH does not inhibit protein synthesis.

The rat AC activity was inhibited by SS, which is in agreement with the literature $[17,30,31]$. A relatively high concentration of SS $\left(10^{-4} \mathrm{M}\right)$ was required to produce this inhibition. This concentration is the same as that used by other authors in their experiments on rat [17] and human [30,31] AC activity. Despite this relatively high concentration, however, several lines of evidence suggest that the effect of SS is receptor-mediated and is not a non-specific inhibitory effect. In this regard, the GTP dependency of the inhibitory effect suggests the involvement of a $G$ protein in the response. This finding is consistent with binding studies on postmortem human and on rat brain tissue which have shown that the binding of SS to its recognition site is affected by GTP in a 
manner consistent with the involvement of a $G$ protein [30,31]. In addition, Nagao et al. [61] and Schettini et al. [17] have shown that SS-reduced cAMP formation in the rat brain occurs via a $G$ protein coupled to AC. These findings, plus the lack of an inhibitory effect of SS $(1 \mu \mathrm{M})$ on basal AC activity in primary cultures of mouse embryonic glial cells reported by Chneiweiss et al. [62] would argue against a non-specific inhibitory effect of the neuropeptide.

The attenuation of the inhibitory activity of SS on AC activity in the $\alpha$-FMH $(6 \mathrm{~h})$-treated rats is most likely related to the observed loss of SS receptors since the basal and FK-stimulated $\mathrm{AC}$ activities were similar in the control and $\alpha$-FMH-treated group, indicating that the catalytic subunit of $\mathrm{AC}$ is intact. In addition, functional $\mathrm{G}_{\mathrm{i}}$ activity, as determined by the effect of Gpp(NH)p on FK-stimulated AC activity in frontoparietal cortex membranes, was similar in the control and $\alpha$-FMH-treated group, suggesting that there is no impairment in the coupling of the SS receptor to $\mathrm{AC}$.

In conclusion, some of the effects of $\alpha$-FMH may well depend on a decrease in the SS receptor/effector system. Thus, SS administered i.c.v. decreases slow-wave sleep [3,4], induces motor excitation [8] and potentiates learning and memory [6,7], whereas $\alpha$-FMH has opposite effects on these activities $[19,36,63]$. From the present results, it would appear that endogenous histamine located in neuronal cells plays a role in modulating the sensitivity to SS in the frontoparietal cortex.

\section{Acknowledgements}

We express our sincere thanks to Dr. J. Kollonitsch (Merck, Sharp and Dome, Rathway, USA) for the supply of $\alpha$-FMH. We would also like to thank Angela Martin for her excellent technical assistance. This work was supported by a grant from the Dirección General de Investigación Científica y Técnica of Spain.

\section{References}

[1] Kalivas, P.W., Histamine-induced arousal in the conscious and pentobarbital-pretreated rat, J. Pharmacol. Exp. Ther., 222 (1982) 37-42.
[2] Tasaka, K., Chung, Y.H., Sawada, K. and Mio, M., Excitatory effect of histamine on the arousal system and its inhibition by $\mathrm{H}_{1}$ blockers, Brain Res. Bull., 22 (1989) 271-275.

[3] Rezek, M., Havlicek, V., Hughes, K.R. and Friesen, H., Cortical administration of somatostatin (SRIF): effect on sleep and motor behavior, Pharmacol. Biochem. Behav., 5 (1976) 73-77.

[4] De Saint Hilaire-Kafi, Z., Charnay, Y., Mikolajewski, R. and Gaillard, J.M., Active immunization against bombesin, cholecystokinin and somatostatin: effects on sleep and feeding, Neurosci. Res. Commun., 9 (1991) 13-19.

[5] Kamei, C. and Tasaka, K., Effect of histamine on memory retrieval in old rats, Biol. Pharm. Bull., 16 (1993) 128-130.

[6] Vécsei, L., Bollok, I. and Telegdy, G., Comparative studies with cyclic and linear somatostatin on active avoidance behaviour and open-field activity in rats, Acta Physiol. Hung., 61 (1983) 43-49.

[7] De Noble, V.J., Hepler, D.J. and Barto, R.A., Cysteamine-induced depletion of somatostatin produces differential cognitive deficits in rats, Brain Res., 482 (1989) 42-48.

[8] Rezek, M., Havlicek, V., Hughes, K.R. and Friesen, H., Behavioural and motor excitation and inhibition induced by the administration of small and large doses of somatostatin into the amygdala, Neuropharmacology, 16 (1977) 157-162.

[9] Panula, P., Yang, H.Y. and Costa, E., Histamine-containing neurons in the rat hypothalamus, Proc. Natl. Acad. Sci. USA, 81 (1984) 2572-2576.

[10] Takeda, N., Inagaki, S., Taguchi, Y., Tohyama, M., Watanabe, T. and Wada, H., Origins of histamine-containing fibers in the cerebral cortex of rats studied by immunohistochemistry with histidine decarboxylase as a marker and transection, Brain Res., 323 (1984) 55-63.

[11] Epelbaum, J., Tapia-Arancibia, L., Kordon, C. and Enjalbert, A., Characterization, regional distribution and subcellular distribution of ${ }^{125} \mathrm{I}^{-\mathrm{Tyr}^{1}}{ }^{1}$-somatostatin binding sites in rat brain, J. Neurochem., 38 (1982) 1515-1523.

[12] Cacabelos, R., Niigawa, H., Yamatodani, A., Gomez-Pan, A., Nishimura, T., Wada, H., Antagonistic effects of growth hormone-releasing factor and somatostatin on brain histamine, Endocrinology, 122 (1988) 1269-1276.

[13] Puebla, L. and Arilla, E., Exogenous histamine increases the somatostatin receptor/effector system in the rat frontoparietal cortex, Eur. J. Pharmacol., in press.

[14] Kollonitsch, J., Patchett, A.A., Marburg, S., Maycock, A.L., Perkins, L.M., Doldouras, G.A., Duggan, D.E. and Aster, S.D., Selective inhibitors of biosynthesis of aminergic neurotransmitters, Nature, 274 (1978) 906-908.

[15] Watanabe, T., Yamatodani, A., Maeyama, K. and Wada, H., Pharmacology of alpha-fluoromethylhistidine, a specific inhibitor of histidine decarboxylase. Trends Pharmacol. Sci., 11 (1990) 363-367.

[16] Sakamoto, C., Nagao, M., Matozaki, T., Nishizaki, H., Konda, Y. and Baba, S., Somatostatin receptors on rat cerebrocortical membranes. Structural characterization of somatostatin-14 and somatostatin-28 receptors and comparison with pancreatic type receptors, J. Biol. Chem., 263 (1988) 14441-14445. 
[17] Schettini, G., Florio, T., Meucci, O., Landolfi, E., Grimaldi, M., Ventra, C. and Marino, A., Somatostatin inhibition of adenylate cyclase activity in different brain areas, Brain Res., 492 (1989) 65-71.

[18] Barrios, V., Rodríguez-Sánchez, M.N. and Arilla, E., The effect of chronic administration of nicotine and withdrawal on somatostatin concentration and binding in brain of rat, Neuropharmacology, 29 (1990) 1025-1030.

[19] Noble, E.P., Wurtman, R.J. and Axelrod, J., A simple and rapid method for injecting $\mathrm{H}^{3}$-norepinephrine into the lateral ventricle of the rat brain, Life Sci., 6 (1967) 281-291.

[20] Kamei, C., Okumura, Y. and Tasaka, K., Influence of histamine depletion on learning and memory recollection in rats, Psychopharmacology, 111 (1993) 376-382.

[21] Glowinski, J. and Iversen, L.L., Regional studies of catecholamines in the rat brain. I. The disposition of $\left[{ }^{3} \mathrm{H}\right]$ norepinephrine, $\left[{ }^{3} \mathrm{H}\right]$ dopamine and $\left[{ }^{3} \mathrm{H}\right]$ DOPA in various regions of the brain, J. Neurochem., 13 (1966) 655-669.

[22] Yamatodani, A., Fukuda, H., Wada, H., Iwaeda, T. and Watanabe, T., High-performance liquid chromatographic determination of plasma and brain histamine without previous purification of biological samples: cation exchange chromatography coupled with post-column derivatization fluorometry, J. Chromatogr., 344 (1985) 115-123.

[23] Patel, J.C. and Reichlin, S., Somatostatin in hypothalamus, extrahypothalamic brain and peripheral tissues of the rat, Endocrinology, 102 (1978) 523-531.

[24] Greenwood, F.C., Hunter, W.M. and Glover, J.S., The preparation of ${ }^{131} \mathrm{I}$-labeled human growth hormone of high specific radioactivity, Biochem. J., 89 (1963) 114-123.

[25] Reubi, J.C., Perrin, M.H., Rivier, J.E. and Vale, V., High affinity binding sites for the somatostatin- 28 analogue in rat brain, Life Sci., 28 (1981) 2191-2198.

[26] Lowry, O.H., Rosebrough, N.J., Farr, A.L. and Randall, R.J., Protein measurement with Folin phenol reagent, J. Biol. Chem., 193 (1951) 265-275.

[27] Czernik, A.J. and Petrack, V., Somatostatin receptor binding in rat cerebral cortex. Characterization using a nonreducible somatostatin analog, J. Biol. Chem., 285 (1983) 5525-5530.

[28] Aguilera, G., Parker, D.S. and Catt, K.J., Characterization of somatostatin receptors in the rat adrenal glomerulosa zone, Endocrinology, 111 (1982) 1376-1384.

[29] Houslay, M.D., Metcalfe, J.C., Warren, G.B., Hesketh, T.R. and Smith, G.A., The glucagon receptor of rat liver plasma membranes can couple to adenylate cyclase without activating it, Biochim. Biophys. Acta, 436 (1976) 489-494.

[30] Gilman, A.G., A protein binding assay for adenosine $3^{\prime} 5^{\prime}$ cyclic monophosphate, Proc. Natl. Acad. Sci. USA, 67 (1970) 305-312.

[31] Bergström, L., Garlind, A., Nilsson, L., Alafuzoff, I., Fowler, C.J., Winblad, B. and Cowburn, R.F., Regional distribution of somatostatin receptor binding and modulation of adenylyl cyclase activity in Alzheimer's disease brain, J. Neurol. Sci., 105 (1991) 225-233.

[32] Garlind, A., Fowler, C.J., Alafuzoff, I., Winblad, B. and Cowburn, R.F., Neurotransmitter-mediated inhibition of post-mortem human brain adenylyl cyclase, J. Neural Transm., 87 (1992) 113-124.

[33] Munson, P.J. and Rodbard, D., LIGAND: a versatile computerized approach for characterization of ligand binding systems, Anal. Biochem., 107 (1980) 220-239.

[34] Scatchard, G., The attractions of proteins for small molecules and ions, Ann. N.Y. Acad. Sci., 51 (1949) 660-671.

[35] Young, P., Kirkham, D.M., Murphy, G.J. and Cawthorne, M.A., Evaluation of inhibitory guanine nucleotide regulatory protein $G_{i}$ function in hepatocyte and liver membranes from obese Zucker $(\mathrm{fa} / \mathrm{fa}$ ) rats and their lean (fa/?) littermates, Diabetologia, 34 (1991) 565-569.

[36] Oishi, R., Nishibori, M., Itoh, Y., Saeki, K., Fukuda, T. and Araki, Y., Histamine turnover in the brain of morphine-dependent mice, Naunyn-Schmiedeberg's Arch. Pharmacol., 337 (1988) 58-63.

[37] Cacabelos, R. and Alvarez, X.A., Histidine decarboxylase inhibition induced by $\alpha$-fluoromethylhistidine provokes learning-related hypokinetic activity, Agents Actions, 33 (1991) 131-134.

[38] Pollard, G., Bischoff, S. and Schwartz, J.C., Turnover of histamine in rat brain and its decrease under barbiturate anesthesia, J. Pharmacol. Exp. Ther., 190 (1974) 88-99.

[39] Picatoste, F., Blanco, I. and Palacios, J.M., The presence of two cellular pools for rat brain histamine, J. Neurochem., 29 (1977) 735-737.

[40] Hough, L.B., Khandelwal, J.K. and Green, J.P., Histamine turnover in regions of rat brain, Brain Res., 291 (1984) 103-109.

[41] Saeki, K. and Oishi, R., Histaminergic neurons: morphology and functions. In: T. Watanabe and H. Wada (Eds.), CRC Press, Boston, 1991, pp 345-364.

[42] Garbarg, M., Barbin, G., Rodergas, E. and Schwartz, J.C., Inhibition of histamine synthesis in brain alpha-fluoromethylhistidine, a new irreversible inhibitor; in vitro and in vivo studies, J. Neurochem., 35 (1980) 1045-1052.

[43] Maeyama, K., Watanabe, T., Taguchi, Y., Yamatodani, A. and Wada, H., Effects of $\alpha$-fluoromethylhistidine, a suicide inhibitor of histidine decarboxylase, on histamine levels in the mouse tissue, Biochem. Pharmacol., 31 (1982) 23672370.

[44] Maeyama, K., Watanabe, T., Yamatodani, A., Taguchi, Y., Kambe, H. and Wada, H., Effect of $\alpha$-fluoromethylhistidne on the histamine content of the brain of $\mathrm{W} / \mathrm{W}^{\mathrm{V}}$ mice devoid of mast cells: turnover of brain histamine, J. Neurochem., 41 (1983) 128-134.

[45] Sakurai, E., Niwa, H., Yamasaki, S., Maeyama, K. and Watanabe, T., The disposition of a histidine decarboxylase inhibitor (S)- $\alpha$-fluoromethylhistidine in rats, J. Pharm. Pharmacol., 42 (1990) 857-860.

[46] Schonbrunn, A., Rorstad, O.P., Westendorf, J.M. and Martin, J.B., Somatostatin analogs: correlation between receptor binding affinity and biological potency in GH pituitary cells, Endocrinology, 113 (1983) 1559-1567.

[47] Pitkänen, A., Sirviö, J., Jolkkonen, J. and Riekkinen, P., Somatostatin-like immunoreactivity and somatostatin recep- 
tor binding in rat brain before and after pentylenetetrazol-induced convulsions, Neuropeptides, 7 (1986) 63-71.

[48] Srikant, C.B. and Patel, Y.C., Somatostatin receptors: identification and characterization in rat brain membranes, Proc. Natl. Acad. Sci. USA, 78 (1981) 3930-3934.

[49] de los Frailes, M.T., Cacicedo, L., Lorenzo, M.J., Tolón, R.M., Fernández, G. and Sánchez-Franco, F., Neurotransmitter regulation of somatostatin secretion by fetal rat cerebral cortical cells in culture, J. Endocrinol. Invest., 16 (1993) 661-668.

[50] Robbins, R.J., Sutton, R.E. and Reichlin, S., Effects of neurotransmitters and cyclic AMP on somatostatin release from cultured cerebral cortical cells, Brain Res., 234 (1983) 377-386.

[51] Anden, N.E. and Grabowska, M., Pharmacological evidence for a stimulation of dopamine neurons by noradrenaline neurons in the brain, Eur. J. Pharmacol., 39 (1976) 275-282.

[52] Strombom, U., On the functional role of pre-and post-synaptic catecholamine receptors in brain, Acta Physiol. Scand., 431 (suppl.) (1976) 3-43.

[53] Bell, G.I. and Reisine, T., Molecular biology of somatostatin receptors, Trends Neurosci., 16 (1993) 34-38.

[54] Bruno, J.F., Xu, Y., Song, J. and Berelowitz, M., Tissue distribution of somatostatin receptor subtype ribonucleic acid in the rat, Endocrinology, 133 (1993) 2561-2567.

[55] Ip, N.Y. and Zigmond, R.E., Pattern of presynaptic nerve activity can determine the type of neurotransmitter regulating a post-synaptic event, Nature, 311 (1984) 472-476.

[56] Kilpatrick, D.L., Howells, R.D., Fleminger, G. and Udenfriend, S., Denervation of rat adrenal glands markedly increases prepro-enkephalin mRNA, Proc. Natl. Acad. Sci. USA, 81 (1984) 7221-7223.
[57] Mazurkiewicz-Kwilecki, J. and Nsonwah, S., The influence of $\alpha$-fluoromethylhistidine on the regional brain histamine and plasma corticosterone levels in aging, Can. J. Physiol. Pharmacol., 65 (1987) 2154-2157.

[58] Seltzer, A.M., Donoso, A.O. and Podesta, E., Restraint stress stimulation of prolactin and ACTH secretion: role of brain histamine, Physiol. Behav., 36 (1986) 251-255.

[59] Cacabelos, R., Yamatodani, A., Niigawa, H., Hariguchi, S., Nishimura, T. and Wada, H., Histaminergic neuromodulation of the release of vasopressin, Neuroendocrinology, 45 (1987) 368-375.

[60] Slotkin, T.A., Bartolome, J. and Whitmore, W.L., Developmental effects of $\alpha$-fluoromethylhistidine, an irreversible inhibitor of histidine decarboxylase, on growth and on levels and turnover of catecholamines, Life Sci., 33 (1983) 2137 2145.

[61] Nagao, M., Sakamoto, C., Matozaki, T., Nishizaki, H., Konda, Y., Nakano, O. and Baba, S., Coupling of inhibitory GTP binding protein to somatostatin receptors on rat cerebrocortical membranes, Folia Endocrinol. Jpn., 65 (1989) 1357 1366.

[62] Chneiweiss, J., Glowinski, J. and Prémont, J., Vasoactive intestinal polypeptide receptors linked to an adenylate cyclase and their relationship with biogenic amine and somatostatin-sensitive adenylate cyclase on central neuronal and glial cells in primary culture, J. Neurochem., 44 (1985) $779-786$.

[63] Kiyono, S., Seo, M.L., Shibagaki, M., Watanabe, T., Maeyama, K. and Wada, H., Effects of alpha-fluoromethylhistidine on sleep-waking parameters in rats, Physiol. Behav., 34 (1985) 615-617. 